\title{
Lupinus angustifolius L. cultivar "Boregine" from South of Bulgaria: a source of nutrients and natural biologically active components $^{\not{h}}$
}

\author{
Zhana Petkova $^{1,{ }^{*}}$, Ginka Antova ${ }^{1}$ (D), Maria Angelova-Romova ${ }^{1}$ (D), Ilinka Todorova ${ }^{1}$, \\ Magdalena Stoyanova ${ }^{2}\left([)\right.$ and Albena Stoyanova ${ }^{3}($ \\ ${ }^{1}$ Department of Chemical Technology, University of Plovdiv "Paisii Hilendarski”, 24 Tzar Asen Street, 4000 Plovdiv, Bulgaria \\ 2 Department of Analytical Chemistry and Physicochemistry, University of Food Technologies, 26 Maritza Blvd., 4003 Plovdiv, Bulgaria \\ ${ }^{3}$ Department of Tobacco, Sugar, Vegetable and Essential Oils, University of Food Technologies, 26 Maritza Blvd., 4003 Plovdiv, \\ Bulgaria
}

Received 23 October 2021 - Accepted 31 January 2022

\begin{abstract}
Nowadays, the requirements of new sources of natural food components are constantly expanding worldwide. On one hand, the constituents derived from the common agriculture plants satisfy the needs of the body to function properly. On the other hand, the price of producing ordinary foods is gradually increasing. For that reason, it is necessary to find a cheaper alternative industrial crops, such as a specific variety of lupin (Lupinus angustifolius L. cultivar "Boregine"). The chemical and lipid composition of lupin seeds as well as the physicochemical characteristics of the oil were examined. The seeds are rich in proteins and carbohydrates, mainly starch, but have low oil content. Sucrose was the main soluble sugar and the major amino acids were phenylalanine, arginine, tyrosine and serine. Linoleic and oleic acids were predominate in the oil; $\beta$-sitosterol and $\gamma$-tocopherol were the main components in the sterol and tocopherol fractions, respectively. Phosphatidylinositol and phosphatidylcholine represented more than $50 \%$ of all phospholipids and oleic acid was in the highest amount in all phospholipid classes. All physicochemical characteristics of lupin seed oil were in agreement with the requirements for edible oils and its oxidative stability at $100{ }^{\circ} \mathrm{C}$ and an air flow rate of $20 \mathrm{~L} / \mathrm{h}$ was extremely high (more than $100 \mathrm{~h}$ ). Lupin seeds have high nutritional value and their oil depicts to be stable, which makes them a possible source of high quality lipids with long shelf life.
\end{abstract}

Keywords: Lupinus angustifolius L. cultivar "Boregine" / chemical composition / biologically active compounds / physicochemical characteristics / South of Bulgaria

Résumé - Le cultivar «Boregine » Lupinus angustifolius L. du Sud de la Bulgarie: une source de
nutriments et de composants naturels biologiquement actifs. De nos jours, les besoins en nouvelles
sources de composants alimentaires naturels sont en constante augmentation dans le monde entier. D'une
part, les composants dérivés de plantes agricoles communes répondent aux besoins nutritionnels de
l'homme. D'autre part, le prix de production des aliments de base augmente progressivement. Pour cette
raison, il est nécessaire de trouver des cultures industrielles alternatives moins chères, comme une variété
spécifique de lupin (Lupinus angustifolius L., cultivar «Boregine»). La composition chimique et lipidique
des graines de lupin ainsi que les caractéristiques physicochimiques de l'huile ont été examinées. Les
graines sont riches en protéines et en hydrates de carbone, principalement en amidon, mais présentent une
faible teneur en huile. Le saccharose est le principal sucre soluble et les principaux acides aminés sont la
phénylalanine, l'arginine, la tyrosine et la sérine. Les acides linoléique et oléique prédominent dans l'huile;
le $\beta$-sitostérol et le $\gamma$-tocophérol sont respectivement les principaux composants des fractions stérol et
tocophérol. Le phosphatidylinositol et la phosphatidylcholine représentaient plus de $50 \%$ de tous les
phospholipides et l'acide oléique prédominait dans toutes les classes de phospholipides. L'ensemble des
caractéristiques physico-chimiques de 1 'huile de graines de lupin répondait aux exigences des huiles
alimentaires et sa stabilité oxydative à $100^{\circ} \mathrm{C}$ et à un débit d'air de $20 \mathrm{~L} / \mathrm{h}$ était extrêmement élevée (plus de

it Contribution to the Topical Issue "Creating new oil \& protein crop value chains / Construire de nouvelles filières oléoprotéagineuses".

*Correspondence: zhanapetkova@uni-plovdiv.net 
$100 \mathrm{~h}$ ). Les graines de lupin possèdent une valeur nutritionnelle élevée et leur huile est stable, ce qui en fait une source possible de lipides de haute qualité avec conservation de longue durée.

Mots clés : Lupinus angustifolius L. cultivar «Boregine» / composition chimique / composés biologiquement actifs / caractéristiques physico-chimiques / sud de la Bulgarie

\section{Highlights}

The chemical and lipid composition of seeds from Lupinus angustifolius L. cultivar "Boregine" as well as physicochemical characteristics of the oil were examined in detail for the first time. The seeds have high nutritional value. The oil is rich in fat-soluble bioactive components and has long shelf life.

\section{Introduction}

Legumes are considered to be important plants, because they are a main source of proteins for the human body. They are widespread in Asia and America and are used as animal feed and human consumption. In the recent years, it has been observed a lack of protein consumption in Europe, which encourages the cultivation of legumes that are characterized with high protein content (25-31.33\%) (Bakoglu et al., 2009; Kökten et al., 2010). The bean crops, in Bulgaria, occupy less area than wheat, and the most common are chickpeas, peas, lentils, beans, and soybeans, which are the richest in protein of all legumes. The proteins from the legumes are biologically complete because they contain all necessary amino acids as well as all of the essential ones. Protein, derived from beans, is the cheapest and can be used as an additive to increase the protein content of foods, feeds, etc. They are also unique foods because of their rich content of other nutrients such as starch, fibres, oligosaccharides and minerals.

Over the past few years, the cost of growing and producing conventional foods (corn, soybean, and wheat) are constantly increasing, so it is necessary to find a cheaper alternative way. There is an ongoing search for new raw materials that contain more essential fatty and amino acids; tocopherols, carotenoids, phospholipids and sterols that are not synthesized in the human body but are provided only by the food, and their balanced intake is important for protecting the health.

Therefore, there is an increasing interest in some nontraditional crops that could be the source of new functional food ingredients rich in valuable nutrients and biologically active substances. Such representatives are the plants from the Fabaceae family. Lupin seeds (Lupinus angustifolius L.) can be offered as an alternative to the main legumes. Lupin belongs to the Fabaceae family and is believed to contain all essential amino acids, making its protein preferable for consumption. Recently, lupin has become a source of protein in the food industry, and may even replace soybeans in some of the markets worldwide. According to some studies, these seeds are also useful in the prevention of cardiovascular disease because they have the potential to lower the cholesterol level (Starkute et al., 2016).
Besides that, the climatic conditions in Bulgaria are favorable for the cultivation of lupin, especially in areas with acidic soils and where other legumes do not normally develop.

The studies on lupin seeds worldwide are focused mainly on their chemical composition as follow: oil content (3.88-12.58\%), proteins $(28.4-45.9 \%)$, carbohydrates (41.60-51.68\%), starch (3.00-10.26\%), fibres (8.05-22.20\%), ash (2.9-4.8\%), non-nitrogenous extracts $(285.9-436.5 \mathrm{~g} / \mathrm{kg}$ ) (Mohamed and Rayas-Duarte, 1995; Bartkiene et al., 2016; Sedláková et al., 2016; Lara-Rivera et al., 2017; Tarasenko et al., 2017) and the lipid composition comprises the fatty acid composition, the total and individual tocopherol composition, and the total content of sterols and phospholipids. The composition of the seeds varies within certain limits and depends on the type of lupin, the geographical location, and the climatic conditions in which the respective plant species are grown.

Unsaturated fatty acids predominate in the fatty acid composition of triacylglycerols, such as oleic (31.9-66.2\%), linoleic (13.7-48.3\%), and linolenic (5.4-12.8\%) (Hansen and Czochanska, 1974; Alamri, 2012; Rybiński et al., 2018). The fatty acid composition also varies widely depending on the geographical area where the plant is grown. In the fatty acid composition of lipids from seeds of Russian lupin varieties, oleic acid prevails (57.0\%) (Tarasenko et al., 2017), while in those from the Baltic republics linoleic acid predominates (41.7-48.0\%) (Bartkiene et al., 2016). In the lipids of Egyptian lupin seeds, oleic acid is predominant (41.9\%) and the content of linoleic is much lower (23.4\%) (Hassanein et al., 2011).

Major classes of tocopherols are present in the tocopherol fraction $(\alpha-, \gamma$ - and $\delta$-tocopherols) and $\gamma$-tocopherol prevails. Total content of phospholipids and monoglycerides in the lipids is $1.18-2.24 \%$ and sterols are about $4.0 \%$ (Alamri, $2012)$. It is found that total lipids $(8.6 \%)$ derived from lupin seeds of the species L. angustifolius var. Uniwhite consists of triglycerides $(71.1 \%)$, phospholipids $(14.9 \%)$, free sterols $(5.2 \%)$, glycolipids $(3.5 \%)$, sterol esters $(0.5 \%)$, free alcohols $(0.4 \%)$, hydrocarbons $(0.4 \%)$, and waxes $(4.0 \%)$ (Hansen and Czochanska, 1974).

In the past few years, specific cultivars of lupin with low alkaloid content have been developed, which makes them really suitable for human consumption (Mihailović et al., 2008). One of this species is Lupinus angustifolius cultivar "Boregine" which have been under examination about their possible introduction in Serbia (Mihailović et al., 2008). On the other hand, the information of the chemical and lipid composition of this specific cultivar of lupin is rather limited. In order to evaluate the possible application of L. angustifolius cultivar "Boregine" seeds and depict them as a potential alternative food, the main purpose of the current study is to determine in detail the proximate composition of the seeds from the above mentioned lupin cultivar grown in Bulgaria. 


\section{Materials and methods}

\subsection{Materials}

The investigations were carried out with lupin seeds (L. angustifolius German cultivar "Boregine") which were provided from a manufacturer in Bulgaria. The seeds were harvested at the full maturity and the weight of 1000 seeds was $128 \mathrm{~g}$. The seeds were grown in the southern part of Bulgaria (elev. $200 \mathrm{~m} ; 42^{\circ} 29^{\prime} 8.12^{\prime \prime} \mathrm{N} ; 2^{\circ} 78^{\prime} 1.53^{\prime \prime} \mathrm{E}$ ) and harvested in 2018 (average temperature: $17^{\circ} \mathrm{C}$; average humidity: $67 \%$; average pressure: $1011 \mathrm{mbar}$; precipitation: $603 \mathrm{~mm}$ ). The seeds were ground into a flour before the analysis, using laboratory mill in order to pass through 30 mesh sieve. Then, the samples were kept in a closed container in the refrigerator (at $5^{\circ} \mathrm{C}$ ) prior the analysis.

\subsection{Chemical composition}

Crude fiber, moisture, ash content, and total protein were determined according to AOAC (2016). Carbohydrate content was calculated as follows: $100-($ weight in grams [protein + lipids + water + ash] in $100 \mathrm{~g}$ of dry seeds) (FAO, 2003). The soluble carbohydrates and the starch content were identified by using standard methods (BS 7169, 1989; BS 13488, 1976). The oil was extracted from the seeds in a Soxhlet using $n$-hexane (ISO 659, 2014).

The energy value of the seeds was determined according to FAO (2003)'s procedure using the formula below:

$$
\mathrm{EV}=\mathrm{C} \times 4+\mathrm{L} \times 9+\mathrm{P} \times 4(\mathrm{kcal} / 100 \mathrm{~g}),
$$

where $\mathrm{EV}$ is the energy value, $\mathrm{C}$ is the total carbohydrates $(\%)$, $\mathrm{L}$ is the total lipids (\%), and $\mathrm{P}$ is the total proteins $(\%)$.

\subsection{Soluble sugars}

Soluble sugars are determined by high performance liquid chromatography (HPLC) on an Agilent LC 1220 instrument (USA) equipped with Zorbax Carbohydrate column $(150 \times 4.6 \mathrm{~mm}$; pore size: $70 \AA$; particle size: $5.0 \mu \mathrm{m}$, Agilent $)$ and Zorbax Reliance Cartridge guard-column (Agilent) and refractive index detector (RID 1260) (Georgiev et al., 2012). The mobile phase was acetonitrile/water $\left(\mathrm{AcN} / \mathrm{H}_{2} \mathrm{O}\right)(80 / 20)$ at $1.0 \mathrm{~mL} / \mathrm{min}$. All individual pure monosaccharides (purity 98\%) were purchased from Merck (Darmstadt, Germany).

\subsection{Amino acids}

The seeds $(300 \mathrm{mg})$ were hydrolyzed with $6 \mathrm{~N} \mathrm{HCl}$ solution at $105^{\circ} \mathrm{C}$ for $24 \mathrm{~h}$ and after that, dried in a vacuum chamber at $50{ }^{\circ} \mathrm{C}$. The residue was diluted with $20 \mathrm{mM} \mathrm{HCl}$ and filtered. The derivatization was performed with AccQ-Fluor kit (WATO52880, Waters Corporation, USA) and $20 \mu \mathrm{L}$ of the filtrate were used. The solution was heated to $55^{\circ} \mathrm{C}$ and $20 \mu \mathrm{L}$ were injected. An ELITE LaChrome HPLC chromatograph (Hitachi) equipped with a diode array detector (DAD) and a reverse phase $\mathrm{C} 18 \mathrm{AccQ}-\mathrm{Tag}$ column $(3.9 \times 150 \mathrm{~mm}$; particle size: $4 \mu \mathrm{m}$; packing material: Silica base bonded with $\mathrm{C}_{18}$ ) was used. The mobile phases in the gradient elution were
WATO52890 buffer (Waters Corporation, USA) and 60\% acetonitrile in a double distilled water. The detection wavelength was $254 \mathrm{~nm}$ and the column temperature was $37^{\circ} \mathrm{C}$ (Popova et al., 2021).

\subsection{Physicochemical characteristics of glyceride oil}

The physicochemical properties (iodine, acid, peroxide, saponification values, refractive index, and relative density) of the oil were analyzed following the standard procedures (AOCS, 1999; EN ISO 6320, 2000; ISO/FDIS 3657, 2001; ISO 3960, 2007; ISO 660, 2009; ISO 6883, 2017). Oxidative stability is measured at $100{ }^{\circ} \mathrm{C}$ and an air flow rate of $20 \mathrm{~L} / \mathrm{h}$ by Rancimat 679 equipment (Metrohm Switzerland) (ISO 6886, 2006).

\subsection{Fatty acid composition}

Fatty acid composition of the glyceride oil was determined by gas chromatography (GC) (ISO 12966-1, 2014). Fatty acid methyl esters (FAMEs) were prepared by transesterification of the oil with sulfuric acid in methanol (ISO 12966-2, 2011). Determination was performed on HP 5890 gas chromatograph equipped with a capillary column Supelco of $30 \mathrm{~m} \times 0.25 \mathrm{~mm}$ $\times 0.2 \mu \mathrm{m}$ (film thickness) and a flame ionization detector (FID). The column temperature was programmed from $70^{\circ} \mathrm{C}$ $(1 \mathrm{~min})$, at $6^{\circ} \mathrm{C} / \mathrm{min}$ to $190^{\circ} \mathrm{C}(3 \mathrm{~min})$, and at $10^{\circ} \mathrm{C} / \mathrm{min}$ to $240{ }^{\circ} \mathrm{C}$; the injector and detector temperatures were $250{ }^{\circ} \mathrm{C}$; the carrier gas was hydrogen. Identification was carried out by comparison of the retention times with those of a standard mixture of FAME.

\subsection{Phospholipids}

Ground seeds were subjected to extraction with a mixture of chloroform and methanol (2:1, v/v) (Folch et al., 1957). Individual phospholipids were isolated by two-dimensional thin-layer chromatography (TLC) (Schneiter and Daum, 2006). Identification was performed by comparing the $R_{f}$ values with authentic standards. The spots of phospholipids were scrapped and mineralized with a mixture of perchloric and sulphuric acid, 1:1 (v/v), and the quantification was performed spectrophotometrically at $700 \mathrm{~nm}$ (ISO 10540-1, 2014). The total phospholipids were determined in the seeds and then their quantity in the lipids was calculated on the basis of the oil content of the seeds.

Fatty acids of phosphatidylcholine (PC), phosphatidylinositol (PI), phosphatidylethanolamine (PE), and phosphatidic acids (PA) were isolated from the phospholipid fraction by preparative TLC. They were subjected to saponification with $2 \mathrm{~N} \mathrm{KOH}$ in ethanol and extracted with hexane. After that, the preparation of the FAME and their GC determination were the same as for the glyceride oil described in Section 2.6. (Supplementary Material 1).

\subsection{Sterols}

Glyceride oil was subjected to saponification and the unsaponifiables were extracted with n-hexane (ISO 18609, 
2000). Total sterols were measured spectrophotometrically (at $597 \mathrm{~nm}$ ) after the isolation of sterols from the unsaponifiable matter by TLC (Ivanov et al., 1972).

Sterol composition was determined on HP 5890 gas chromatograph equipped with DB 5 capillary column $(25 \mathrm{~m}$ $\times 0.25 \mathrm{~mm} \times 0.25 \mu \mathrm{m}$ (film thickness)) and FID. Temperature gradient was from $90{ }^{\circ} \mathrm{C}(3 \mathrm{~min})$ up to $290^{\circ} \mathrm{C}$ at a rate of change of $15^{\circ} \mathrm{C} / \mathrm{min}$ and then up to $310^{\circ} \mathrm{C}$ at a rate of $4{ }^{\circ} \mathrm{C} / \mathrm{min}$ (10 min); detector temperature: $320^{\circ} \mathrm{C}$; injector temperature: $300^{\circ} \mathrm{C}$ and carrier gas was hydrogen. Identification was confirmed by comparison of retention times with those of a standard mixture of sterols (ISO 12228-1, 2014) (Supplementary Material 2).

\subsection{Tocopherols}

Tocopherols were determined by high performance liquid chromatography with Nucleosil Si 50-5 column $(250 \times 4 \mathrm{~mm}$, particle size: $5 \mu \mathrm{m}$ ), fluorescent detection at $295 \mathrm{~nm}$ excitement and $330 \mathrm{~nm}$ emission. The operating conditions were the mobile phase of hexane:dioxane, 96:4 (v/v) and flow rate of $1 \mathrm{~mL} / \mathrm{min}$ (ISO 9936, 2016). The total tocopherols were determined in the oil and then their quantity in the seeds was calculated on the basis of their oil content.

\subsection{Carotenoids}

Total carotenoid content was determined according to method described by Borello and Domenici (2019). The measurement was done spectrophotometrically at $470 \mathrm{~nm}$.

\subsection{Statistics}

All measurements were performed in triplicate $(n=3)$ and the results were presented as mean value \pm standard deviation (SD).

\section{Results and discussions}

\subsection{Chemical composition}

Main chemical compositions (proteins, carbohydrates, oil, ash, fibers and moisture) of the lupin seeds (L. angustifolius cultivar "Boregine") are presented in Table 1.

The protein content of the examined lupin seeds was $23.9 \%$, which confirmed that these seeds belonged to the legumes with high total protein content (23.0-31.33\%) (Iqbal et al., 2006; Bakoglu et al., 2009; Kökten et al., 2010) and possessed a high nutritional value. The obtained results corresponded to the findings from previous authors who reported that the total proteins in lupin seeds ranged from 28.4 to $45.8 \%$ (Sedláková et al., 2016; Tarasenko et al., 2017; Bartkiene et al., 2016; Mohamed and Rayas-Duarte, 1995; Lara-Rivera et al., 2017). On the other hand, these seeds had rather low oil content $(7.4 \%)$ but it was higher than those in other seeds from Fabaceae family (1.0-3.0\%). Their oil content was similar to those of corn germ and oats (5.0\%) but it was significantly lower than those of soybeans (17.0-20.0\%). Similar results about the oil content were observed also in the seeds from different lupin varieties (6.9-14.1\%) (Mohamed
Table 1. Chemical composition of lupin seeds.

\begin{tabular}{lc}
\hline Chemical composition & Lupin seeds \\
\hline Proteins, \% & $23.9 \pm 0.4$ \\
Oil content, \% & $7.4 \pm 0.4$ \\
Carbohydrates & $57.1 \pm 0.9$ \\
» starch, \% & $24.1 \pm 0.2$ \\
» water-soluble sugars, \% & $4.1 \pm 0.2$ \\
» fibres, \% & $10.1 \pm 0.6$ \\
Ash, \% & $3.9 \pm 0.2$ \\
Moisture, \% & $7.7 \pm 0.2$ \\
Energy value, $\mathrm{kJ} / 100 \mathrm{~g}(\mathrm{kcal} / 100 \mathrm{~g})$ & $1658(391)$ \\
\hline
\end{tabular}

and Rayas-Duarte, 1995; Sedláková et al., 2016; Tarasenko et al., 2017; Rybiński et al., 2018), but Borek et al. (2009) and Mohamed and Rayas-Duarte (1995) observed that the oil content of the seeds from Lupinus mutabilis и Lupinus angustifolius was higher (19.0-20.0\%). Contrariwise, Lara-Rivera et al. (2017) and Bartkiene et al. (2016) reported that the oil content of the seeds from six accessions of Lupinus angustifolius ranged from 3.88 to $5.80 \%$.

The examined lupin seeds possessed a higher carbohydrate content $(57.1 \%)$ than the results obtained by other researchers (42.24-52.28\%) (Mohamed and Rayas-Duarte, 1995; Bartkiene et al., 2016; Lara-Rivera et al., 2017). The studied seeds had a significantly higher starch content (24.1\%) than the results obtained by previous authors who examined the seeds of different lupin species Lupinus albus and Lupinus angustfolius (2.81-4.53\%) (Mohamed and Rayas-Duarte, 1995; Kohajdová et al., 2011). It was established that the starch content of all examined lupin seeds was lower than those of other legumes (30-50\%). The content of available sugars in the examined lupin seeds $(4.1 \%)$ was higher than the results by Kohajdová et al. (2011) (1.21-2.58\%).

Recently, there has been a growing emphasis on fiber content, which is important for the normal digestion. Leguminous plants contain a great amount of these substances and, given their high protein and carbohydrate content, these crops are suitable foods for human consumption. The results showed that the fiber content of lupin seeds was $10.1 \%$, which corresponded well with the results from previous studies on the fiber content of the seeds of different lupin species (8.05-15.4\%) (Sedláková et al., 2016; Lara-Rivera et al., 2017). Higher values for the fibers $(22.2 \%)$ were obtained by Tarasenko et al. (2017) who examined the chemical composition of the meal from lupin seeds cultivated in Russia.

Legumes are rich in minerals (potassium, calcium, phosphorus, iron, zinc, etc.). For that reason, was examined the total mineral content (ash) of lupin seeds. The ash content was $3.9 \%$, which was in agreement with the ash content of different legume seeds $(3.0-4.9 \%)$ examined in previous studies. They also corresponded to the finding about lupin seeds of Lara-Rivera et al. (2017) (3.13-3.51\%), Bartkiene et al. (2016) (3.0-4.3\%) and Mohamed and Rayas-Duarte (1995) (4.0-4.4\%).

The moisture content of the lupin seeds $(7.7 \%)$ was close to the previous findings for different lupin species (8.3-9.7\%) (Tarasenko et al., 2017; Bartkiene et al., 2016), but it was 
Table 2. Composition of soluble sugars in lupin seeds.

\begin{tabular}{lc}
\hline Content, $\mathrm{mg} / 100 \mathrm{~g}$ & Lupin seeds \\
\hline Fructose & $244.9 \pm 2.1$ \\
Glucose & $221.6 \pm 10.8$ \\
Galactose & $186.5 \pm 14.6$ \\
Xylose & $109.5 \pm 6.1$ \\
Rhamnose & $109.4 \pm 3.3$ \\
Sucrose & $2341.4 \pm 141.3$ \\
Cellobiose & $883.1 \pm 9.5$ \\
\hline
\end{tabular}

higher than the results reported by Lara-Rivera et al. (2017) who examined six varieties of Lupinus angustifolius (3.59-4.38\%).

The tested lupin seeds had a high content of their main components, which determined their high energy value $(1658 \mathrm{~kJ} / 100 \mathrm{~g}$ or $391 \mathrm{kcal} / 100 \mathrm{~g})$.

Table 2 presents the content of soluble carbohydrates in lupin seeds.

Five monosaccharides and two disaccharides were detected in the seeds. Total content of water soluble carbohydrates was found to be $4096.2 \mathrm{mg} / 100 \mathrm{~g}$. The fructose $(244.9 \mathrm{mg} / 100 \mathrm{~g})$ was found in the highest amount among all monosaccharides, followed by glucose $(221.6 \mathrm{mg} / 100 \mathrm{~g})$ and galactose $(186.5 \mathrm{mg} / 100 \mathrm{~g})$. The content of xylose and rhamnose were detected in similar quantities (109.5 and $109.4 \mathrm{mg} / 100 \mathrm{~g}$, respectively). The main disaccharide was found to be sucrose $(2341.4 \mathrm{mg} / 100 \mathrm{~g})$ and the amount of cellobiose was much lower $(883.1 \mathrm{mg} / 100 \mathrm{~g})$. Similar results about the content of fructose were obtained by Piotrowicz-Cies lak (2005) (from 1.33 to $2.80 \mathrm{mg} / \mathrm{g}$ ) who examined the composition of soluble carbohydrates of lupin seeds from Mediterranean Sea. According to the same author, only the seeds from variety L. pilosus possessed higher content of fructose $(6.26 \mathrm{mg} / \mathrm{g})$. On the other hand, the content of glucose and galactose of the lupin seeds in the present study was higher than that observed by Piotrowicz-Cies lak (2005) (from 0.07 to $0.89 \mathrm{mg} / \mathrm{g}$ for glucose and from 0 to $0.85 \mathrm{mg} / \mathrm{g}$ for galactose). The content of sucrose, reported by the mentioned author (from 18.86 to $27.9 \mathrm{mg} / \mathrm{g}$ ) was similar to our results, apart from varieties L. pilosus where the amount of sucrose was higher $(32.65 \mathrm{mg} / \mathrm{g})$, and L. palaestinus and L. hispanicus subsp. hispanicus where the quantity was lower (15.6 and $15.54 \mathrm{mg} / \mathrm{g}$, respectively).

Table 3 shows the results about the content of amino acids ( $\mathrm{mg}$ amino acid (AA)/g sample) in the examined lupin seeds.

Seventeen amino acids were identified in the seeds. The major amino acid was phenylalanine $(24.8 \mathrm{mg} / \mathrm{g})$, followed by arginine $(13.6 \mathrm{mg} / \mathrm{g})$, tyrosine $(12.8 \mathrm{mg} / \mathrm{g})$, and serine $(12.6 \mathrm{mg} / \mathrm{g})$. On the other hand, leucine $(1.4 \mathrm{mg} / \mathrm{g})$, lysine $(2.8 \mathrm{mg} / \mathrm{g})$, proline $(2.8 \mathrm{mg} / \mathrm{g})$, and valine $(2.9 \mathrm{mg} / \mathrm{g})$ were identified in the lowest content. The amount of the other amino acids was observed to range between 3.2 and $11.5 \mathrm{mg} / \mathrm{g}$. These results differed significantly from others where leucine was found to be in the highest content $(7.05-9.34 \%$ from total amino acids) while methionine $(0.15-1.38 \%$ from total amino acids) was with the lowest content in all examined seeds from variety L. angustifolius (Starkute et al., 2016). Overall, lupin
Table 3. Amino acid composition of lupin seeds.

\begin{tabular}{lr}
\hline Amino acid, mg AA/g & Lupin seeds \\
\hline Aspartic acid & $7.1 \pm 0.2$ \\
Serine & $12.6 \pm 0.1$ \\
Glutamic acid & $7.1 \pm 0.1$ \\
Glycine & $3.2 \pm 0.2$ \\
Histidine & $11.5 \pm 0.2$ \\
Arginine & $13.6 \pm 0.3$ \\
Threonine & $5.8 \pm 0.2$ \\
Alanine & $3.8 \pm 0.1$ \\
Proline & $2.8 \pm 0.1$ \\
Cysteine & $7.8 \pm 0.3$ \\
Tyrosine & $12.8 \pm 0.1$ \\
Valine & $2.9 \pm 0.2$ \\
Methionine & $5.0 \pm 0.1$ \\
Lysine & $2.8 \pm 0.2$ \\
Isoleucine & $9.7 \pm 0.3$ \\
Leucine & $1.4 \pm 0.1$ \\
Phenylalanine & $24.8 \pm 0.2$ \\
\hline
\end{tabular}

seeds as all leguminous plants were deficient in methionine, cystine and cysteine (Iqbal et al., 2006).

\subsection{Physicochemical characteristics of lupin seed oil}

Physicochemical characteristics are important indicators for the quality of the glyceride oils and play a role in the establishing of their shelf life. The main physicochemical characteristics of lupin seed oil have been determined and the results are shown in Table 4.

The peroxide value of the crude glyceride oil of lupin seeds met the requirements for peroxide value of vegetable oils (up to $15 \mathrm{meqO}_{2} / \mathrm{kg}$ ) and was close to that of oil isolated from sweet and bitter types of lupin seeds (1.85 and $1.97 \mathrm{meqO}_{2} / \mathrm{kg} ; 1.80$ and $1.89 \mathrm{meqO}_{2} / \mathrm{kg}$ ) (Alamri, 2012; Khalid and Elhardallou, 2019).

The acid value of the examined oil was higher than the requirements for edible oils $(4.0 \mathrm{mgKOH} / \mathrm{g})$ and much higher than the results reported by Alamri (2012) (0.935 and $0.853 \mathrm{mgKOH} / \mathrm{g})$. This difference in the acid values is probably caused by the higher amount of linoleic acid in the examined oil while the same author indicates that in the bitter and sweet lupin seed oil the predominant fatty acid is oleic (52.22 and 44.93\%, respectively). According to Negash et al. (2019) the higher the fatty acid unsaturation, the higher the acid value of the oils.

The results for relative density and refractive index were within the limits of the requirements for these indicators for vegetable oils (Codex-Stan 210, 1999).

Saponification value of the lupin seed oil was higher than the results reported by Alamri (2012) (192.92 and $187.90 \mathrm{mgKOH} / \mathrm{g}$ ) and Khalid and Elhardallou (2019) (193.54 and $190.0 \mathrm{mgKOH} / \mathrm{g}$ ).

The iodine value, which was an indicator of the degree of unsaturation of fatty acids in oils, was relatively high $\left(116 \mathrm{gI}_{2} / 100 \mathrm{~g}\right)$ and this was due to the higher content of 
Table 4. Physicochemical characteristics of lupin seed oil.

\begin{tabular}{lc}
\hline Physicochemical characteristics & Lupin seed oil \\
\hline Peroxide value, $\mathrm{meqO}_{2} / \mathrm{kg}$ & $2.5 \pm 0.3$ \\
Acid value, $\mathrm{mgKOH} / \mathrm{g}$ & $6.0 \pm 0.2$ \\
Iodine value, $\mathrm{gI}_{2} / 100 \mathrm{~g}$ & $116 \pm 2.0$ \\
Saponification value, $\mathrm{mgKOH} / \mathrm{g}$ & $231 \pm 2.0$ \\
Relative density, $20^{\circ} \mathrm{C}$ & $0.9022 \pm 0.0002$ \\
Refractive index, $20^{\circ} \mathrm{C}$ & $1.4770 \pm 0.0008$ \\
Oxidative stability, $\mathrm{h}$ & 105 \\
\hline
\end{tabular}

unsaturated fatty acids in the lupin seed oil. These values were close to that reported by Alamri (2012): 118.4 and $108.7 \mathrm{gI}_{2} / 100 \mathrm{~g}$. This makes it possible to classify lupin seed oil as semi-dry oil, characterized by an iodine value between $100-150 \mathrm{gI}_{2} / 100 \mathrm{~g}$. The iodine value of lupin seeds oil was close to that of rapeseed oil $\left(94-120 \mathrm{gI}_{2} / 100 \mathrm{~g}\right)$ and sesame oil (104-120 $\left.\mathrm{gI}_{2} / 100 \mathrm{~g}\right)$ (Codex-Stan 210, 1999).

Despite the higher iodine value, the oil had a very high oxidative stability (the induction period was $105 \mathrm{~h}$, which was probably due to the high amount of tocopherols and carotenoids.

\subsection{Lipid composition of the oil}

Lipids are biological components which include more than 1000 different compounds and the major lipid groups are fatty acids, triacylglycerols, phospholipids, glycolipids, sterols, isoprenoids, etc. They are an important nutrient, a major source of energy, and a major carrier of fat-soluble vitamins. Essential fatty acids, linoleic and linolenic, are extremely important in the formation of cell membranes, especially neural tissue.

The lipid composition of glyceride oil isolated from lupin seeds (Lupinus angustifolius L. cultivar "Boregine") was also examined, including fatty acid composition the composition of some representatives of unsaponifiables (sterols, tocopherols and carotenoids), the content and composition of phospholipids, as well as the fatty acid composition of the major phospholipid classes.

The content of biologically active substances (sterols, tocopherols, carotenoids and phospholipids) in glyceride oil and in lupin seeds are present in Table 5.

Unsaponifiable matters in the examined oil was $3.0 \%$, which was higher than the results about the content of unsaponifiables in other seed oils (0.9-2.0\%) (Codex-Stan $210,1999)$. These results were similar to the data about bitter and sweet types of lupin seed oils (3.51-3.66\%) (Alamri, 2012). The sterol content of the oil was $1.0 \%$, which was significantly lower than the results obtained by Alamri (2012) (4.32-4.11\%), but it was much higher than these by Hassanein et al. (2011) (0.19\%). On the other hand, total sterol content of lupin seed oil was similar to those of rapeseed oil $(1.1 \%)$ (Codex-Stan 210, 1999).

It was observed a high content of tocopherols (vitamin E) in the lipids and seeds: $1585 \mathrm{mg} / \mathrm{kg}$ and $117.3 \mathrm{mg} / \mathrm{kg}$, respectively. The total content of tocopherols in lupin seed oil was close to that of palm, sunflower and soybean oils (1500, 1520 and $1680 \mathrm{mg} / \mathrm{kg}$ ) (Codex-Stan 210, 1999; O'Brien et al.,
Table 5. Content of biologically active components in the glyceride oil and seeds from lupin.

\begin{tabular}{lc}
\hline Biologically active components & Lupin seed oil \\
\hline Unsaponifiable matters, \% & \\
in the oil & $3.0 \pm 0.2$ \\
in the seeds & $0.2 \pm 0.0$ \\
Sterols, \% & \\
in the unsaponifiable matters & $34.4 \pm 3.4$ \\
in the oil & $1.0 \pm 0.1$ \\
in the seeds & $0.07 \pm 0.0$ \\
Tocopherols, $\mathbf{m g} / \mathbf{k g}$ & \\
in the oil & $1585 \pm 14$ \\
in the seeds & $117.3 \pm 1.0$ \\
Carotenoids, $\mathbf{~ m g / k g}$ & \\
in the oil & $2068 \pm 50$ \\
in the seeds & $153 \pm 4$ \\
Phospholipids, \% & \\
in the oil & $5.5 \pm 0.5$ \\
in the seeds & $0.4 \pm 0.1$ \\
\hline
\end{tabular}

2000), but it was twice higher than the reported amounts in the oils isolated from bitter and sweet lupin seed oils (795.7 and $635.8 \mathrm{mg} / \mathrm{kg}$ ) (Alamri, 2012), and the data obtained by Hassanein et al. (2011) (939 mg/kg).

Lupin seed oil contained $2068 \mathrm{mg} / \mathrm{kg}$ of carotenoids which amount was similar to the carotenoid content of other crude vegetable oils (500-2500 mg/kg) (Codex-Stan 210, 1999). Carotenoids, such as $\alpha$ - and $\beta$-carotene and lycopene, have antioxidant properties and provitamin A activity.

The content of phospholipids in the isolated oil was 5.5\%, and in the seeds it was $0.4 \%$, respectively. It was established that a higher amount of phospholipids was found in the lipids of the examined lupin seeds compared to the results reported by Alamri (2012) $(2.24 \%$ and $1.18 \%$ for lupin seed oils from bitter type and sweet type, respectively). The total phospholipid content was higher than that in other vegetable oils (1.0-1.5\%) (Codex-Stan 210, 1999; O’Brien et al., 2000).

Lupin seeds possessed relatively low oil content but were rich in biologically active substances, such as tocopherols, carotenoids, phospholipids and sterols.

\subsubsection{Fatty acid composition}

Fatty acid composition of the oils may vary in some limits, depending on the climatic conditions where the plants are grown. It also serves to evaluate the quality and nutritional properties of the oil. The fatty acid composition was determined by gas chromatography of the corresponding methyl esters.

Fatty acid composition of the lupin seed oil is presented in Table 6.

Nineteen fatty acids were identified in lupin seed oil. Linoleic acid (41.0\%) was the major component in the triacylglycerols, followed by oleic $(32.9 \%)$, palmitic $(11.9 \%)$ and stearic $(7.4 \%)$ acids. It was established that the amount of the essential linolenic acid was rather higher (4.4\%) than in the sunflower oil, but the content of the same fatty acid in lupin 
Table 6. Fatty acid composition of lupin seed oil.

\begin{tabular}{lc}
\hline Fatty acids, \% & Lupin seed oil \\
\hline Caprylic $\left(\mathrm{C}_{8: 0}\right)$ & $0.1 \pm 0.02$ \\
Capric $\left(\mathrm{C}_{10: 0}\right)$ & $0.1 \pm 0.0$ \\
Lauric $\left(\mathrm{C}_{12: 0}\right)$ & $0.1 \pm 0.05$ \\
Myristic $\left(\mathrm{C}_{14: 0}\right)$ & $0.3 \pm 0.1$ \\
Myristoleic $\left(\mathrm{C}_{14: 1}\right)$ & $0.2 \pm 0.1$ \\
Pentadecanoic $\left(\mathrm{C}_{15: 0}\right)$ & $0.1 \pm 0.05$ \\
Palmitic $\left(\mathrm{C}_{16: 0}\right)$ & $11.9 \pm 0.9$ \\
Palmitoleic $\left(\mathrm{C}_{16: 1}\right)$ & $0.2 \pm 0.1$ \\
Margaric $\left(\mathrm{C}_{17: 0}\right)$ & $0.1 \pm 0.05$ \\
Stearic $\left(\mathrm{C}_{18: 0}\right)$ & $7.4 \pm 0.9$ \\
Oleic $\left(\mathrm{C}_{18: 1}\right)$ & $32.9 \pm 2.8$ \\
Linoleic $\left(\mathrm{C}_{18: 2}\right), \mathrm{n}-6$ & $41.0 \pm 2.5$ \\
Linolenic $\left(\mathrm{C}_{18: 3}\right), \mathrm{n}-3$ & $4.4 \pm 1.7$ \\
Arachidic $\left(\mathrm{C}_{20: 0}\right)$ & $0.2 \pm 0.05$ \\
Eicosadienoic $\left(\mathrm{C}_{20: 2}\right), \mathrm{n}-6$ & $0.1 \pm 0.02$ \\
Eicosatrienoic $\left(\mathrm{C}_{20: 3}\right), \mathrm{n}-3$ & $0.2 \pm 0.05$ \\
Behenic $\left(\mathrm{C}_{22: 0}\right)$ & $0.1 \pm 0.02$ \\
Erucic $\left(\mathrm{C}_{22: 1}\right)$ & $0.2 \pm 0.05$ \\
Docosahexaenoic $\left(\mathrm{C}_{22: 6}\right), \mathrm{n}-3$ & $0.4 \pm 0.1$ \\
$\mathbf{\Sigma}$ n-6 & $\mathbf{4 1 . 1}$ \\
$\mathbf{\Sigma}$ n-3 & $\mathbf{5 . 0}$ \\
Ratio n-3/n-6 & $\mathbf{0 . 1 2}$ \\
\hline & \\
\hline
\end{tabular}

seed oil was closed to that of soybean oil (5-11\%) (Codex-Stan 210, 1999).

Fatty acid composition of the examined oil was also similar to those of sesame, soybean and sunflower oils (Codex-Stan 210, 1999). Other than that, it was close to the fatty acid composition of oils from different types of lupin seeds (Lupinus albus and L.angustifolius), where the main components were also linoleic (41.7-48.3\%), oleic (25.2-31.2\%), palmitic (4.2-11.4\%) and linolenic (0.1-7.9\%) acids (Hansen and Czochanska, 1974; Bartkiene et al., 2016).

It was established that the ratio $n-3 / n-6$ in the tested oil was lower than those reported by Rybiński et al. (2018) (0.51\%) who examined seed oil from variety L.albus. This indicated that the examined seed oil had lower content of n-3 fatty acids.

The content of saturated and unsaturated (mono- and polyunsaturated) fatty acids in the lupin seed oil is shown in Figure 1.

The amount of unsaturated fatty acids (UFA) predominated in the oil (79.6\%) and the content of polyunsaturated fatty acids (PUFA) was higher (46.1\%) than those of monounsaturated fatty acids (MUFA) $(33.5 \%)$. The main representatives of PUFA were linoleic and linolenic acids, while in the MUFA was oleic acid.

The obtained results correlated well with these from previous studies for seed oils from L. angustifolius, where the content of UFA were $78.6 \%$ (Bartkiene et al., 2016) and from sp81.1-87.0\% (Bartkiene et al., 2016; Alamri, 2012). On the other hand, according to Rybiński et al. (2018) the relative percent of the UFA in the oils from different accessions of L. albus varied from 41.2 to $66.2 \%$, which was twice less than the present data.

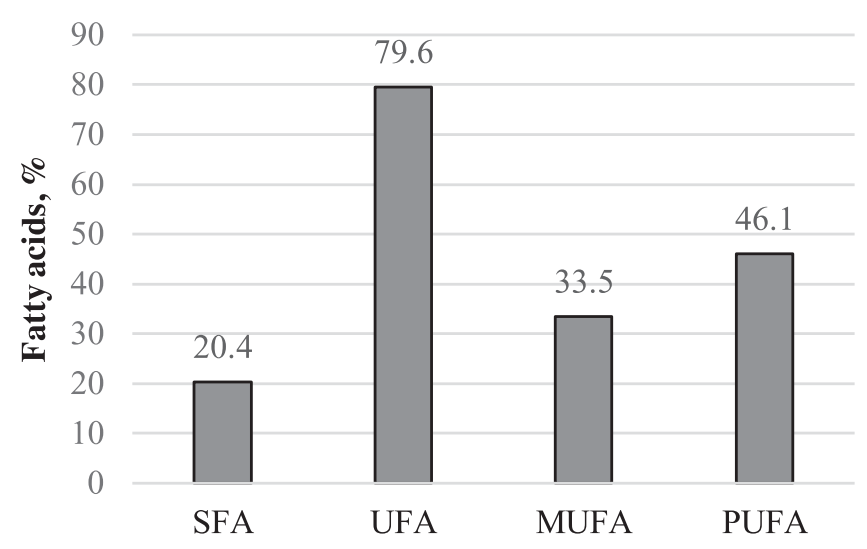

Fig. 1. Content of saturated (SFA), unsaturated (UFA), monounsaturated (MUFA) and polyunsaturated (PUFA) fatty acids in lupin seed oil.

Table 7. Individual sterol, tocopherol and phospholipid composition of lupin seed oil.

\begin{tabular}{lr}
\hline Components & Lupin seed oil \\
\hline Sterols, \% & \\
Cholesterol & $1.0 \pm 0.2$ \\
Campesterol & $24.3 \pm 0.5$ \\
Stigmasterol & $3.3 \pm 0.3$ \\
$\beta$-sitosterol & $71.3 \pm 1.1$ \\
$\Delta^{7}$-stigmasterol & $0.1 \pm 0.0$ \\
Tocopherols, \% & \\
$\alpha$-tocopherol & $5.2 \pm 0.2$ \\
$\gamma$-tocopherol & $92.2 \pm 0.6$ \\
$\gamma$-tocotrienol & $2.6 \pm 0.5$ \\
Phospholipid, \% & \\
Phosphatidylcholine & $21.2 \pm 3.2$ \\
Phosphatidylinositol & $33.8 \pm 1.5$ \\
Phosphatidylethanolamine & $6.6 \pm 1.1$ \\
Sphingomyelin & $5.8 \pm 1.1$ \\
Phosphatidylserine & $3.5 \pm 1.0$ \\
Phosphatidic acids & $7.1 \pm 1.7$ \\
Lysophosphatidylcholine & $6.1 \pm 1.4$ \\
Lysophosphatidylethanolamine & $8.9 \pm 1.6$ \\
Monophosphatidylglycerol & $7.0 \pm 1.2$ \\
\hline
\end{tabular}

The content of SFA was relatively lower $(20.4 \%)$ and the main representatives were palmitic (11.9\%) and stearic (7.4\%) acids.

\subsubsection{Sterol, tocopherol and phospholipid composition}

Sterol, tocopherol and phospholipid composition of the lupin seed oil are presented in Table 7 .

The main component of the sterol fraction was $\beta$-sitosterol (71.3\%), followed by campesterol (24.3\%). These results were close to the sterol composition of oils from lupin seeds, cultivated in Egypt where $\beta$-sitosterol also predominated $(54.6 \%)$, followed by campesterol (27.9\%) and stigmasterol (11.2\%) (Hassanein et al., 2011). The content of campesterol 
Table 8. Fatty acid composition of the main phospholipid classes.

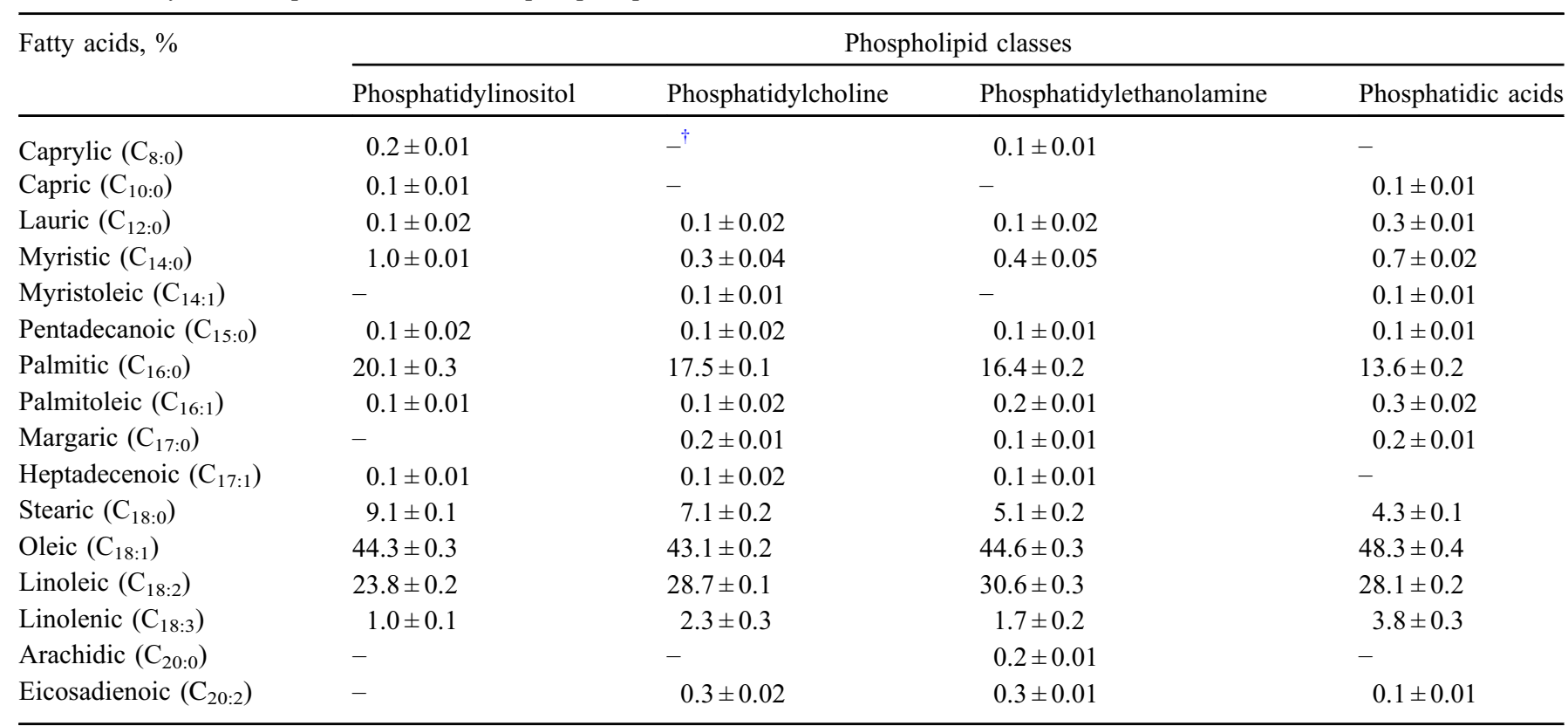

\footnotetext{
${ }^{\dagger}$ Not detected.
}

in lupin seed oil was in the given limits for crude oils in Codex-Stan 210 (1999): from 6.4 to 38.6\%. Cholesterol and stigmasterol contents in the lipids of lupin seeds were found to be relatively low (1.0 and $3.3 \%$, respectively).

Two main tocopherols were identified in the examined lupin seed oil ( $\alpha$ - and $\gamma$-tocopherols). The main component was $\gamma$-tocopherol $(92.2 \%)$, while $\alpha$-tocopherol was found in small quantities $(5.2 \%)$. The only representative from the unsaturated tocopherols was $\gamma$-tocotrienol which was also found in low amounts $(2.6 \%)$.

Present results were similar to the tocopherol composition of oils from lupin seeds, cultivated in Egypt where $\gamma$-tocopherol $(93.6 \%)$ predominated, followed by $\alpha$ - and $\delta$-tocopherols $(3.4$ and $3.0 \%$, respectively) (Hassanein et al., 2011).

Tocopherol composition of the examined oil was similar to those of soybean, corn and sesame oils (Codex-Stan 210, 1999). On the other hand, the individual tocopherol composition of lupin seed oil was completely different from these of other seed oils (such as sunflower, safflower, etc.) where the main component was $\alpha$-tocopherol (Codex-Stan 210, 1999).

Nine phospholipid classes were identified in lupin seed oil. Phosphatidylinositol (33.8\%) and phosphatidylcholine $(21.2 \%)$ predominated in the fraction. Low amount of phosphatidylserine $(3.5 \%)$ was established, while the content of the other phospholipids were from 5.8 to $8.9 \%$.

Phospholipid composition of lupin seeds differed from other legumes (soybean, lentil, peas, vigna, etc.), that contained bigger amount of phosphatidylcholine (35.0-46.0\% of total phospholipids) (Codex-Stan 210, 1999).

Fatty acid composition of the main phospholipid classes (phosphatidylinositol, phosphatidylcholine, phosphatidylethanolamine and phosphatidic acids) has been also examined and the results are shown in Table 8 .

Oleic acid (43.1-48.3\%) predominated in all phospholipid classes, followed by linoleic $(23.8-30.6 \%)$ and palmitic

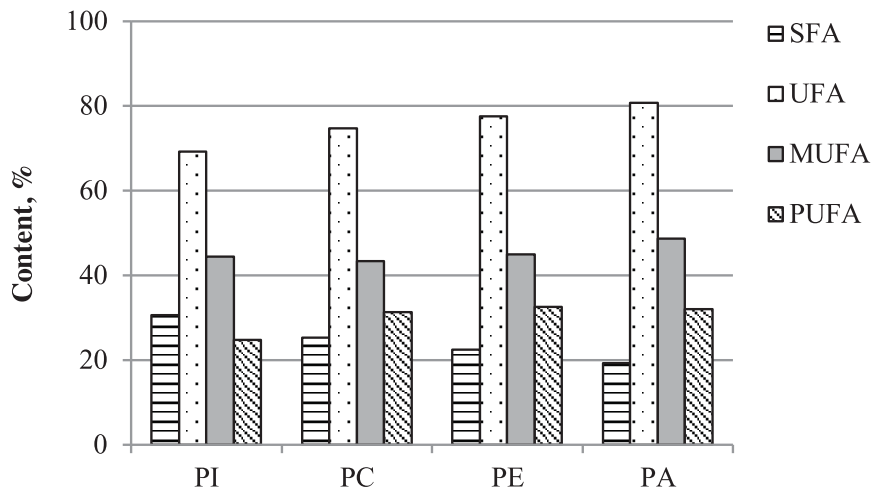

Fig. 2. Content of saturated (SFA), unsaturated (UFA), monounsaturated (MUFA) and polyunsaturated (PUFA) fatty acids of the main phospholipid classes. ${ }^{\dagger}$ PI: Phosphatidylinositol; PC: Phosphatidylcholine; PE: Phosphatidylethanolamine; PA: Phosphatidic acids.

(13.6-20.1\%) acids. The other main saturated fatty acid was stearic with amount between 4.3 and $9.1 \%$. The quantity of the essential linolenic acid varied from 1.0 to $3.8 \%$ and the content of the other fatty acids was insignificant $(0.1-1.0 \%)$.

A tendency of increasing the amount of oleic acid was observed in the direction: phosphatidylcholine $<$ phosphatidylinositol $<$ phosphatidylethanolamine $<$ phosphatidic acids, while for linoleic acid was: phosphatidylinositol $<$ phosphatidic acids $<$ phosphatidylcholine $<$ phosphatidylethanolamine.

The contents of palmitic and stearic acids decreased in the direction: phosphatidylinositol $>$ phosphatidylcholine $>$ phosphatidylethanolamine $>$ phosphatidic acids.

The content of total saturated and unsaturated fatty acids of the main phospholipid classes in lupin seed oil is presented in Figure 2. 
The content of SFA increased in the following direction: phosphatidic acids $(19.3 \%)<$ phosphatidylethanolamine $(22.5 \%)<$ phosphatidylcholine $(25.3 \%)<$ phosphatidylinositol $(30.7 \%)$. A decrease of the UFA was observed in the same direction. The amount of the MUFA remained almost unchanged in all examined phospholipid classes (43.4-48.7\%), while those of PUFA increased in the following direction: phosphatidylinositol $<$ phosphatidylcholine $<$ phosphatidic acids $<$ phosphatidylethanolamine.

Fatty acid composition of the main phospholipids did not differ significantly from those of glyceride oil. Linoleic acid $(41.0 \%)$ predominated in the latters, while the amount of the same fatty acid in the phospholipid fraction was $23.8-36.0 \%$ which was at the expense of the higher quantity of oleic acid (43.1-48.3\%). It was established that there were not significant differences in the content of SFA, but differences were observed in the amount of MUFA and PUFA (33.5:46.1\% in the glyceride oil, and $43.4-48.7 \%: 24.8-32.6 \%$ in the phospholipids).

The differences in the fatty acid composition could be explained by the different stages of biosynthesis of the separated phospholipids on the one hand and triacylglycerols on the other. The saturated fatty acids were synthesized in the beginning of this process alongside with the phospholipids as follows: first was synthesized phosphatidylinositol, followed by phosphatidylethanolamine, phosphatidic acids and eventually-triacylglycerols. For that reason, more SFA were included in phospholipid molecules - first in phosphatidylinositol and after that in phosphatidylethanolamine, phosphatidic acids and in triacylglycerols when the biosynthesis of polyunsaturated fatty acids also began to accelerate (Munshi et al., 1983).

\section{Conclusion}

Detailed examinations on the chemical and lipid composition of L. angustifolius cultivar "Boregine" seeds were carried out for the first time. According to the results lupin seeds are a promising industrial crop which have a nutritional value, because of their high content of proteins, carbohydrates, dietary fibers and several lipid-soluble biologically active components such as essential fatty acids, tocopherols, sterols, carotenoids and phospholipids. What is more, lupin seed oil depicts to be an alternative source of high quality lipids with a nutritional value and a long shelf life which is due to its extremely high oxidative stability.

\section{Supplementary Material}

Supplementary Material 1. Chromatogram of the fatty acid composition of phosphatidylethanolamine isolated from lupin seeds.

Supplementary Material 2. Chromatogram of sterol composition of lupin seed oil.

The Supplementary Material is available at http://www.ocljournal.org/10.1051/ocl/2022003/olm.

Acknowledgements. This work was supported by the Bulgarian National Science Fund (BNSF), Ministry of Education and
Science, projects of junior basic researchers and postdocs -2018 [grant number КП-06-M29/2, 01/12/2018].

\section{References}

Alamri MS. 2012. Characterization of lupin seed oils extracted from bitter and sweet types. Pak J Food Sci 22(3): 161-167.

AOAC. 2016. Association of Official Analytical Chemist, Official methods of analysis, 20th ed. Washington, DC.

AOCS (American Oil Chemists Society). 1999. Official Methods and Recommended Practices of the American Oil Chemists Society, "Calculated iodine value", 5th ed. Champaign, IL: AOCS Press, p. Cd 1c-8.

Bakoglu A, Bagci E, Ciftci H. 2009. Fatty acids, protein contents and metal composition of some feed crops from Turkey. J Food Agric Environ 7(2): 343-346.

Bartkiene E, Bartkevics V, Starkute V, et al. 2016. Chemical composition and nutritional value of seeds of Lupinus luteus L., L. angustifolius L. and new hybrid lines of L.angustifolius L. Zemdirb Agric 103(1): 107-114.

Borek S, Pukacka S, Michalski K, Ratajczak L. 2009. Lipid and protein accumulation in developing seeds of three lupine species: Lupinus luteus L., Lupinus albus L., and Lupinus mutabilis sweet. $J$ Exp Bot 60(12): 3453-3566.

Borello E, Domenici V. 2019. Determination of pigments in virgin and extra-virgin olive oils: A comparison between two near UVVis spectroscopic techniques. Foods 8(1): 18. https://doi.org/ $10.3390 /$ foods 8010018 .

BS 13488. 1976. Grain. Method for determining the starch content.

BS 7169. 1989. Products of processed fruit and vegetables. Determination of sugar content.

Codex standard for named vegetable oils, Codex-Stan 210-1999, Revisions 2001, 2003, 2009. Amendment 2005, 2011, p. 16.

EN ISO 6320. 2000. Animal and vegetable fats and oils. Determination of Refractive index, p. 6.

Folch J, Lees M, Sloane-Stanley GH. 1957. A simple method for isolation and purification of total lipids from animal tissues. $J$ Biol Chem 226: 497-509.

Food and Agriculture Organization of the United Nations. 2003. Food energy-Methods of analysis and conversion factors. FAO Food and Nutrition Paper, Report of a Technical Workshop, Vol. 77. Rome.

Georgiev Y, Ognyanov M, Yanakieva I, Kussovski V, Kratchanova M. 2012. Isolation, characterization and modification of citrus pectins. J BioSci Biotechnol 1(3): 223-233.

Hansen RP, Czochanska Z. 1974. Composition of the lipids of lupin seed (Lupinus angustifolius L. var."Uniwhite”). J Sci Food Agric 25(4): 409-415.

Hassanein MMM, El-Shami SM, El-Mallah MH. 2011. Investigation of lipids profiles of nigella, lupin and artichoke seed oils to be used as healthy oils. J Oleo Sci 60(3): 99-107.

Iqbal A, Khalil IA, Ateeq N, Khan SM. 2006. Nutritional quality of important food legumes. Food Chem 97(2): 331-335.

ISO 659. 2014. Oilseeds. Determination of oil content (Reference method).

ISO 660. 2009. Animal and vegetable fats and oils. Determination of acid value and acidity, p. 5.

ISO 3960. 2007. Animal and vegetable fats and oils. Determination of peroxide value, p. 9 .

ISO 6883. 2017. Animal and vegetable fats and oils. Determination of conventional mass per volume ("litre weight in air").

ISO 6886. 2006. Animal and vegetable fats and oils. Determination of oxidative stability (Accelerated oxidation test), p. 13. 
ISO 9936. 2016. Animal and vegetable fats and oils. Determination of tocopherol and tocotrienol contents by high-performance liquid chromatography.

ISO 10540-1. 2014. Animal and vegetable fats and oils. Determination of phosphorus content. Part 1: Colorimetric method.

ISO 12228-1. 2014. Part 1: Animal and vegetable fats and oils. Determination of individual and total sterols contents. Gas chromatographic method.

ISO 12966-1. 2014. Animal and vegetable fats and oils. Gas chromatography of fatty acid methyl esters - Part 1: Guidelines on modern gas chromatography of fatty acid methyl esters.

ISO 12966-2. 2011. Animal and vegetable fat and oils. Gas chromatography of fatty acid methyl esters - Part 2: Preparation of methyl esters of fatty acids.

ISO 18609. 2000. Animal and vegetable fats and oils. Determination of unsaponifiable matter. Method using hexane extraction.

ISO/FDIS 3657. 2001. Animal and vegetable fat and oils. Determination of saponification value.

Ivanov S, Bitcheva P, Konova B. 1972. Méthode de détermination chromatographyque et colorimétrique des phytosterols dans les huiles végétales et les concentres steroliques. Rev Franc Corps Gras 19: 177-180.

Khalid II, Elhardallou SB. 2019. Physico-chemical properties and fatty acids composition of bitter and sweet lupine seed. Orient $J$ Chem 35(3). http://doi.org/10.13005/ojc/350332.

Kohajdová Z, Karovičova J, Schmidt Št. 2011. Lupin composition and possible use in bakery-A review. Czech J Food Sci 29(3): 203-211.

Kökten K, Koçak A, Bağci E, Akçura M, Çelik S. 2010. Tannin, protein contents and fatty acid compositions of the seeds of several Vicia L. species from Turkey. Grasas Aceites 61(4): 404-408. https://doi.org/10.3989/gya.021310.

Lara-Rivera AH, Garcia-Alamilla P, Lagunes-Galvez LM, Macias RR, Garcia Lopez PM, Zamora Natera JF. 2017. Functional properties of Lupinus angustifolius seed protein isolates. J Food Qual 2017: Article ID 8675814. http://doi.org/ $10.1155 / 2017 / 8675814$.

Mihailović V, Hill GD, Lazarević B, et al. Performance of blue lupin (Lupinus angustifolius L.) cultivars on a pseudogley soil in
Serbia. In: Palta JA, Berger JB, eds. Proc 12th International Lupin Conference, Perth, Australia, 2008, pp. 51-54.

Mohamed AA, Rayas-Duarte P. 1995. Composition of Lupinus albus. Cereal Chem 72(6): 643-647.

Munshi SK, Sukhija SP, Bahatia IS. 1983. Lipids biosynthesis in developing kernels of almond (Prunus amygdalus Batsch.). Phytochemistry 22: 79-83.

Negash YA, Amare DE, Bitew BD, Dagne H. 2019. Assessment of quality of edible vegetable oils accessed in Gondar City, Northwest Ethiopia. BMC Res Notes 12(1): 793. https://doi. org/10.1186/s13104-019-4831-x.

O'Brien DR, Farr WE, Wan PJ. 2000. Introduction to fats and oils technology, 2nd ed. AOCS Press.

Piotrowicz-Cies lak A. 2005. Composition of seed soluble carbohydrates and ultrastructural diversity of testa in lupins from the Mediterranean region. Acta Soc Bot Pol 74: 281-286. https://doi. org/10.5586/asbp.2005.036.

Popova V, Petkova Z, Ivanova T, Stoyanova M, Mazova N, Stoyanova A. 2021. Lipid composition of different parts of Cape gooseberry (Physalis peruviana L.) fruit and valorization of seed and peel waste. Grasas Aceites 72(2): e402. https://doi.org/10.3989/gya.1256192.

Rybiński W, Święcicki W, Bocianowski J, Börner A, Starzycka-Korbas E, Starzycki M. 2018. Variability of fat content and fatty acids profiles in seeds of a Polish white lupine (Lupinus albus L.) collection. Genet Resour Crop Evol 65(2): 417-431.

Schneiter R, Daum G. 2006. Analysis of yeast lipids. In: Xiao W, ed. Yeast protocol, 2nd ed. Methods in Molecular Biology. Totowa, NJ: Humana Press Inc., pp. 75-84.

Sedláková K, Straková E, Suchý P, Krejcarová J, Herzig I. 2016. Lupin as a perspective protein plant for animal and human nutrition-A review. Acta Vet Brno 85: 165-175.

Starkute V, Bartkiene E, Bartkevics V, Rusko J, Zadeike D, Juodeikiene G. 2016. Amino acids profile and antioxidant activity of different Lupinus angustifolius seeds after solid state and submerged fermentations. J Food Sci Technol 53(12): 4141-4148. https://doi.org/10.1007/s13197-016-2384-8.

Tarasenko NA, Butina EA, Gerasimenko EO, Nikonovich YN. 2017. Investigation into chemical composition of powdered lupine seeds. J Pharm Sci Res 9(6): 1002-1006.

Cite this article as: Petkova Z, Antova G, Angelova-Romova M, Todorova I, Stoyanova M, Stoyanova A. 2022. Lupinus angustifolius L. cultivar "Boregine" from South of Bulgaria: a source of nutrients and natural biologically active components. OCL 29: 10. 